G. Klymenko, Y. Vasylchenko, Ye. Donchenko, Kramatorsk, Ukraine

\title{
QUALITY MANAGEMENT OF CUTTING TOOLS ON HEAVY MACHINES
}

\begin{abstract}
The work is devoted to improving the efficiency of cutting tools on heavy machines by developing a quality management system for its operation, determining rational operating regulations and developing general machine-building standards for cutting. The developed model of the tool operation control system for the first time allowed to systematically consider the structure and relationships of all components of the process. The qualimetric approach to the tool operation process made it possible to develop methods for quantitative assessment of the process quality and substantiate the structure of the preparatory information subsystem.
\end{abstract}

Keywords: quality management; cutting tool; machines; rational operation of the tool; system approach; quality system.

Improving the efficiency of metalworking, introducing resource-saving technologies in mechanical engineering, improving the quality and competitiveness of products is possible without the development of scientifically grounded regulations for the operation of cutting tools, which significantly affect the working conditions and technical and economic indicators of mechanical engineering. Ukraine is implementing international standards ISO 9000 version 2000, which regulate the development of quality management systems for products and processes, the development of standards and regulatory materials [1-3]. In this regard, the issues of certification of production processes, in particular, the processes of operating the cutting tool, the determination of scientifically grounded cutting modes, consumption rates and other regulations for the operation of the tool, are of particular importance.

The solution of these issues is especially important when using cutting tools on heavy machines of high cost. This is what determines the need to reduce their downtime and organize the rational operation of the tool. The large dispersion of processing parameters on heavy machines, the variety of factors that affect the operation process, require an integrated approach to determining the control parameters of the tool operation process, the methodology of which requires development.

Purpose of the present work: increasing the efficiency of using cutting tools on heavy machines by developing a quality management system for the process of its operation, defining rational operating procedures and developing general machine-building standards for cutting.

The methodological basis of the work is a system approach to the study of the process of operating a tool, its conditions and features, the patterns of processes. 
(C) G. Klymenko, Y. Vasylchenko, 2021

Theoretical research is based on the fundamentals of qualimetry, reliability theory, operations research, decision making, probability, and mathematical statistics.

Existing works considered certain aspects of the operation of tools, which concerned medium-sized machines and did not comprehensively investigate the whole process. As a result of the transition to market conditions for the operation of machine-building enterprises, the operating conditions for cutting tools on heavy machines have somewhat changed [4-7]. Foreign and domestic literature sources indicate the growing interest in assessing the quality of various production processes [8-10]. Nevertheless, there are no systematic studies of the quality of the tool operation process, which allow one to take into account all the variety of factors and their relationships that affect the control parameters, in the literature.

The current standards for cutting conditions in Ukraine give very contradictory recommendations, do not take into account modern processed and tool materials, do not take into account modern designs of cutting tools and their reliability, do not fully contain mathematical models that allow the use of computers to determine cutting conditions on heavy machines. The study of the reliability of the tool was limited to operational tests of their reliability. The use of tools for prefabricated structures requires the development of new mathematical models, taking into account complex reliability indicators. The costs of the cutting tool are calculated without taking into account the probabilistic nature of its operation, without taking into account the design of the tool and cutting conditions. Statistical studies of the processing parameters of parts on heavy machins allowed us to establish more common operating conditions for the tool. The work shows that $70 \%$ of the operations that are performed on rough heavy lathes are longitudinal turning of parts with a carbide tool. All parameters of tool operation on heavy machines have a large scatter, which confirms the need to consider the stochastic nature of the tool operation process. All these factors determined the main tasks of scientific research.

Based on the use of principles of the international standard ISO 9000: 2000, a quality system model of the process of operating tools on heavy machines has been developed. When building the structure of the system, the operation of the tool is for the first time considered as a set of processes: organizational, resource management, maintenance of the technological system, preparatory information, processing of parts and providing feedback (assessment, analysis, improvement).

The rational operation of the cutting tool is understood as such a process of its use, in which, along with high productivity and minimal costs, the lowest possible consumption of the tool is achieved with a given reliability and psychophysical load on the machine operator.

A qualimetric approach was used to quantitatively assess the quality of the 
operation process. The developed hierarchical structure of properties that make up the quality of tool operation (Fig. 1) contains properties of purpose, which are characterized by target functions for multi-criteria optimization of the quality of the cutting tool operation process [1]. They represent a vector of process quality management criteria (the number indicates the level of consideration).

$$
U^{-1}=\left(U_{1}^{3}, U_{2}^{3}, U_{3}^{3}, U_{4}^{3}, U_{5}^{3}\right) .
$$

Quality assessment is determined by:

$$
K^{j}{ }_{I}=f\left(P_{I} / P_{I}^{\ni T}\right),
$$

where $K_{I}^{J}$ - assessment of the complex $i$-property at the $j$-level of consideration; $P_{I} u P_{I}^{\ni T}$ - production quality indicators and reference (basic).

The operational quality level (which is considered at level $j+1$ ) is determined by:

$$
y_{\ni}^{j+1}=\sum_{i=1}^{n} K_{i}^{j} \cdot B_{i}^{j},
$$

where $B_{i}^{j}$ - the weight of the $i$-property at the $j$-level of consideration.

Indicators of the levels of properties were determined on the basis of a questionnaire survey, instant observations, long-term statistical studies, laboratory experiments. The basic indicators adopted are the recommendations of norms, standards, and other regulatory documents [2]. An expert assessment of the properties that characterize the quality of operation made it possible to identify the most important of them, which were taken into account when developing an information and preparatory subsystem for the rational operation of the tool (Fig. 2).

Statistical studies of the quality of the operation of tools were used on the basis of an information databank, which calculates more than 5000 cases of machining parts on heavy machines, which are collected at factories in various fields of mechanical engineering.

For theoretical studies of the quality of operation, a methodology and software for a computer have been developed using the theory of qualimetry, as well as a methodology for expert assessment of the quality of tool operation.

To select a tool design from an information databank of designs, it is proposed to use the cluster analysis technique, which is developed on the basis of applied mathematical statistics using a computer (Statistica 5.5 software package).

When forming clusters, the used agglomerative hierarchical cluster-procedure. Instrument designs from the databank are combined into classes that are 
characterized by the area of regulations for their rational operation.

Operational and laboratory tests were carried out with VK8, T5K10, T15K6 carbide tools with wear-resistant coatings, vibration treatment and ion implantation. The acoustic emission method was used to control the quality of the coatings. To assess the mechanical properties of the studied steels $(45,40 \mathrm{Kh}$, ShKh15SG, $12 \mathrm{Kh} 18 \mathrm{~N} 9 \mathrm{~T}, 9 \mathrm{KhS})$, mechanical tests of the samples were carried out in accordance with the standards (DSTU 1497-73). The study of the operational strength of structures in order to determine the correction factors for the feed, which depend on the type of structure, were carried out in accordance with the method of stepwise increasing feed.

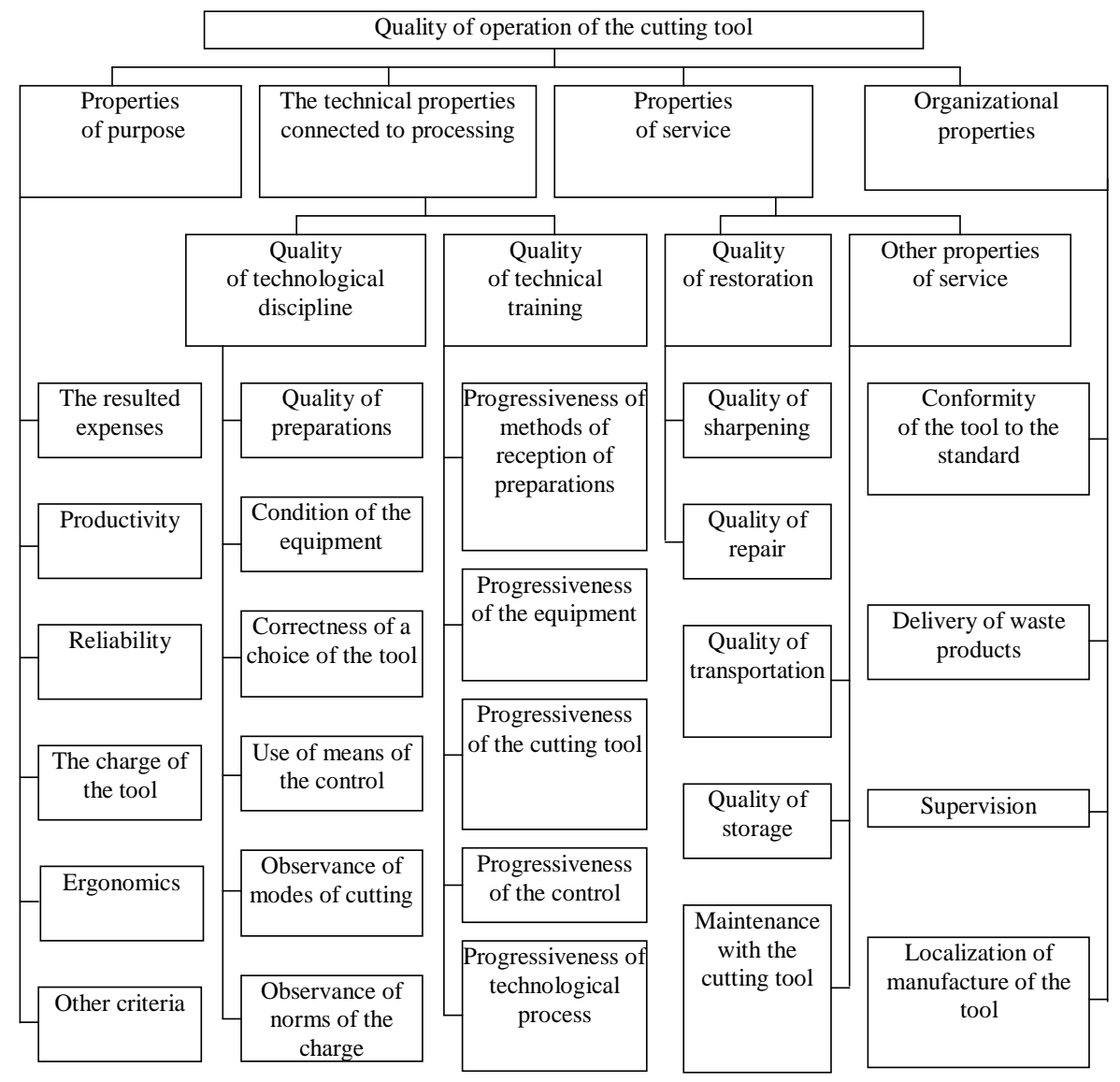


Figure 1 - The system of properties that make up the quality of the tool operation process

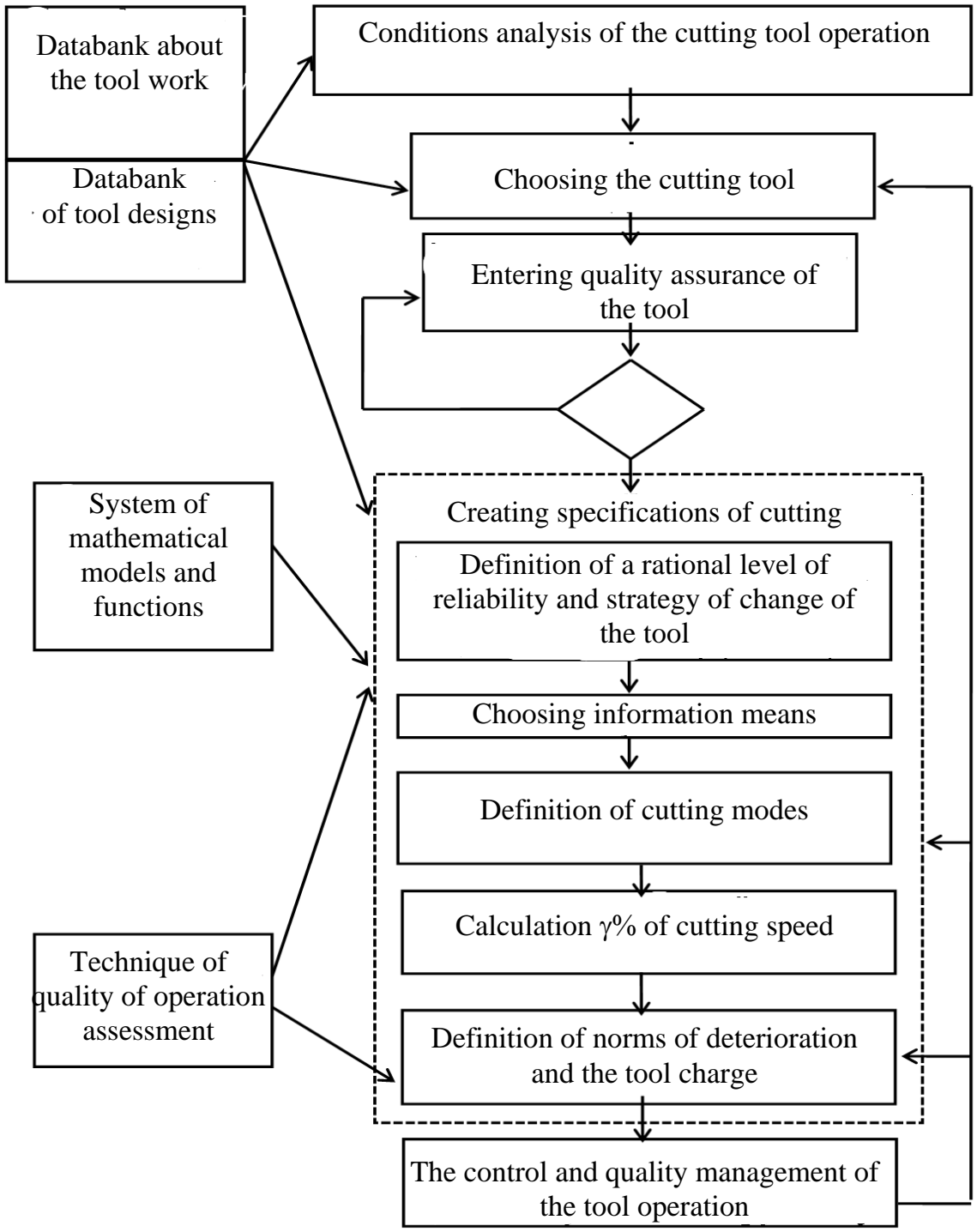

Figure 2 - Structure of the preparatory-information subsystem of cutting tools rational operation 


\section{Conclusions.}

1. For the first time, the new model of the operational process management system considered the structure and capabilities of all the constituent parts of the process.

2. The qualimetric approach to the process of the tool operating made it possible to develop methods for quantitatively assessing the quality of the process and to substantiate the structure of the preparatory information subsystem.

3. The research results were used in the development of general machinebuilding standards for cutting on heavy machines.

References: 1. Klimenko G.P. Definition of a degree of quality of operation of the cutting tool on heavy machine tools // the Bulletin of National technical university of Ukraine "КПI": Machine-building.Kiev: NTUU " КПІ ", 2001.-№.40.- p.337-346. 2. Klimenko G.P. Management of quality of process of operation of the cutting tool on heavy machine tools // High technologies in mechanical engineering. The collection of scientific works NTU "XПI".- Kharkov, 2002.- № 1 (5).-p.157-160. 3. Kovalov V., Vasilchenko Y., Dašić P. Development of the integral complex of optimal control of heavy machine tools adaptive technological system for wind-power engineering parts // 8th International Conference Interdisciplinarity in Engineering, INTER-ENG 2014, 9-10 October 2014, Tirgu Mures, Romania Volume 9, 2015, pp. 145-152 https://doi.org/10.1016/j.protcy.2015.02.022.44._Jedrzejewski, J., Kwasny, $W$. Development of machine tools design and operational properties. Int J Adv Manuf Technol 93, 1051-1068 (2017). https://doi.org/10.1007/s00170-017-0560-2. 5. Jihong Chen, Jianzhong Yang, Huicheng Zhou, Hua Xiang, Zhihong Zhu, Yesong Li, Chen-Han Lee, Guangda Xu, CPS Modeling of CNC Machine Tool Work Processes Using an Instruction-Domain Based Approach, Engineering, Volume 1, Issue 2, 2015, Pages 247-260, ISSN 2095-8099, https://doi.org/10.15302/J-ENG-2015054 . 6. Yanjun Han, Wu-Le Zhu, Lei Zhang, Anthony Beaucamp, Region adaptive scheduling for timedependent processes with optimal use of machine dynamics, International Journal of Machine Tools and Manufacture, Volume 156, 2020, 103589, ISSN 0890-6955, https://doi.org/10.1016/j.ijmachtools.2020.103589. 7. Koji Utsumi, Shoki Shichiri, Hiroyuki Sasahara, Determining the effect of tool posture on cutting force in a turn milling process using an analytical prediction model, International Journal of Machine Tools and Manufacture, Volume 150, 2020, 103511, ISSN 0890-6955, https://doi.org/10.1016/j.ijmachtools.2019.103511. 8. Umut Karagüzel, Emre Uysal, Erhan Budak, Mustafa Bakkal, Analytical modeling of turn-milling process geometry, kinematics and mechanics, International Journal of Machine Tools and Manufacture, Volume 91, 2015, Pages 24-33, ISSN 0890-6955, https://doi.org/10.1016/j.ijmachtools.2014.11.014. 9. Kovalov V., Vasilchenko Y., Turmanidze R., Dašić P., Sukova T., Shapovalov M. The technique of designing high-power CNC lathes for enterprises of the heavy engineering industry. IOP Conference Series: Materials Science and Engineering, Vol. 568 (2019) (Special Volume with: Annual Session of Scientific Papers "IMT ORADEA 2019"; Oradea, Felix Spa; Romania; 30-31 May 2019), Article no. 012119: pp. 1-6. ISSN 1757-8981. https://doi.org/10.1088/1757-899X/568/1/012119. 10. G. Klymenko,Y. Vasylchenko. V. Kvashnin Modeling of cutting tools wear for lathes. Cutting \& Tools in Technological System ISSN: 


\title{
Галина Клименко, Яна Васильченко, Свгеній Донченко, Краматорськ, Україна
}

\section{УПРАВЛІННЯ ЯКІСТЮ РІЗАЛЬНИХ ІНСТРУМЕНТІВ НА ВАЖКИХ ВЕРСТАТАХ}

\begin{abstract}
Анотація. Робота присвячена підвищенню ефективності використання різального інструменту на важких верстатах иляхом розробки системи управління якістю процесу його експлуатації, визначення раціональних регламентів експлуатації та розробки загально-машинобудівних нормативів різання. Методологічною основою роботи є системний підхід до вивчення прочесу експлуатаиії інструменту, його умов та особливостей, закономірностей процесів. Статистичні дослідження параметрів обробки деталей на важких верстатах дозволили встановити найбільш поширені умови експлуатації інструменту. У роботі показано, щчо 70\% операцій, щзо виконуються на чорнових важких токарних верстатах, складає повздовжнє обточування деталей твердосплавним інструментом. Всі параметри експлуатації інструменту на важких верстатах мають велике розсіювання, що підтверджує необхідність розгляду стохастичного характеру процесу експлуатації інструменту. На основі використання принципів міжнародного стандарту ISO 9000: 2000 створена модель системи якості процесу експлуатації інструментів на важких верстатах. Для кількісної очінки якості прочесу експлуатаиії використано кваліметричний підхід. Розроблена ієрархічна структура властивостей, ще складають якість експлуатації інструменту, містить властивості призначення, щуо характеризуються иільовими функиіями для багатокритеріальної оптимізачіі якості процесу експлуатації різального інструменту. Розроблена модель системи керування процесом експлуатації інструменту вперше дозволила системно розглянути структуру та взаємозв'язки усіх складових частин процесу. Кваліметричний підхід до процесу експлуатачії інструменту дав змогу розробити методи кількісної оцінки якості прочесу та обтрунтувати структуру підготовчо-інформаційної підсистеми. Результати досліджень використані при розробці загально-машинобудівних нормативів різання на важких верстатах.
\end{abstract}

Ключові слова: управління якістю; різальний інструмент; верстати; раціональна робота інструменту; системний підхід; система якості. 